\title{
A study on association between tilt angle, solar insolation exposure and output of solar PV panel using BIM 3D modelling
}

\author{
Nur Adibah Ayuni Abd Malek ${ }^{1, *}$, Jian Ming Chew ${ }^{1}$, Nurul Akmam Naamandadin ${ }^{1}$, \\ Norrazman Zaiha Zainol ${ }^{1}$, and Khairunnisa Muhammad ${ }^{1}$ \\ ${ }^{1}$ Civil Engineering Technology Department, Faculty of Civil Engineering Technology, Universiti \\ Malaysia Perlis (UniMAP), 02100 Sg. Chuchuh, Padang Besar, Perlis.
}

\begin{abstract}
Solar PV has been used extensively in the construction industry as non-renewable energy is not environmentally friendly and is costly. Building Information Modelling (BIM) can incorporate the solar energy application to reduce the dependency of non-renewable energy. This study attempted to propose a model of solar analysis using BIM software on existing buildings at Padang Besar, in terms of best orientation and optimum tilt angle. The finding of July 2017 shows that the ideal orientation of solar panel installation for the building is tilted $10^{\circ}$ North and $20^{\circ}$ West. Analysis indicated that the higher solar irradiance harvested contributed towards higher generation of power. The use of BIM software incorporating fieldwork data proved to be more convenient compared to the conventional physical method in proposing options for solar panel installation. The finding from the solar analysis of the proposed model indicates that solar insolation exposure on the roof increased by $1.45 \%$ compared to the existing roof design. Therefore, it can increase the renewable energy potential in an effective way.
\end{abstract}

\section{Introduction}

Solar photovoltaic (PV) is one of the alternative ways to reduce environmental problems due to non-renewable energy. Generation of small-scale solar photovoltaic power (less than 72 $\mathrm{kWp}$ ) has become more common in Malaysia. Malaysia's location, which lies near the equator from $1^{\circ}$ to $7^{\circ}$ North, is strategic to harvest solar energy as the location is exposed to sunlight for an estimated average of 12 hours daily [1-3]. Solar energy exists in the form of electromagnetic radiation with wavelengths ranging from $0.3 \mu \mathrm{m}$ to more than $3 \mu \mathrm{m}$. The pressure-temperature conditions of the Sun's core enable nuclear fusion to take place which causes four protons to convert into a helium core, two positrons, 2 neutrinos and electromagnetic radiation [4]. Field testing for each PV installation is important to improve functionality and cost-effectiveness [5]. Previous studies conducted to observe the effect of the surroundings on solar irradiance reviewed the trend of solar irradiance for each month and varies in terms of time from sunrise to sunset $[6,7]$. The solar irradiance and power

*Corresponding authors: $\underline{\text { adibah.malek@gmail.com }}$ 
generated by a PV panel depend on the relative position of the Sun to the solar ray absorber surface [5]. The more perpendicular the incident ray angle on the absorber surface, the higher the amount of solar irradiance obtained and consequently the greater the power generated by the PV panel.

Irradiance is the amount of light energy which reaches the surface of the receiver measured in square meter per second [8]. The solar irradiance information on Earth is important in the solar energy implementation in terms of photovoltaic cell design, determination of the irradiance amount in the area and the selection of the collector such as PV panel with concentration system [9]. On the other hand, some researchers explained that solar irradiance is the measure of the amount of solar power in the unit of Watt per meter square [10]. The solar irradiance includes the total amount of direct solar irradiance and diffused solar irradiance.

According to Rupesh, solar cells are also named Photovoltaic (PV) cells where the words "Photo" represents light while "Voltaic" represents the production process of electricity [11]. Almost half of the total PV system cost is contributed by a photovoltaic cell module [12]. There are mainly three types of solar panels such as mono-crystalline silicon Photovoltaic Cell, polycrystalline silicon Photovoltaic Cell and thin film amorphous silicon Photovoltaic Cell [13]. A lot of previous research carried out with different research methodologies and locations, as shown in table 1, applied PV modules as the main equipment of their research.

Table 1. List of research involves field testing for determination of optimal PV module tilt angle.

\begin{tabular}{|c|c|}
\hline Resea & System description and location \\
\hline $\begin{array}{c}\text { Zeinab Abdallah M. Elhassan, Mohammad } \\
\text { Fauzi Moh. Zain, Kamaruzzaman Sopian, \& } \\
\text { Arafa Awadalla, (2011) [14] }\end{array}$ & $\begin{array}{l}\text { Five modules with four facing direction } \\
\text { (north, east, south and west) with } 15^{\circ}, 20^{\circ} \\
\text { and } 30^{\circ} \text { of tilt angle at University } \\
\text { Kebangsaan Malaysia. }\end{array}$ \\
\hline $\begin{array}{r}\text { B. Kamanga, J. S. P. Mlat } \\
\text { C. Kamunda, }(20\end{array}$ & $\begin{array}{l}\text { PV module is set to be north-facing with tilt } \\
\text { at angles of } 0^{\circ}, 15^{\circ}, 20^{\circ} \text {, and } 25^{\circ} \text { at Zomba } \\
\text { district. }\end{array}$ \\
\hline $\begin{array}{r}\text { K.R. Ajao, R.M. Ambali, \& M.O. Ma } \\
\text { (2013) [16] }\end{array}$ & $\begin{array}{l}\text { PV module set to be } 0^{\circ} \text { to } 30^{\circ} \text { with a } \\
\text { succession of } 2^{\circ} \text { facing south at Ilorin, } \\
\text { Nigeria. }\end{array}$ \\
\hline $\begin{array}{r}\text { T. Pavlović, Z. Pavlović, L } \\
\text { Kostić, (2010) [ }\end{array}$ & $\begin{array}{l}\text { PV modules set to be } 0^{\circ}, 30^{\circ}, 45^{\circ}, 60^{\circ} \text { and } 90^{\circ} \\
\text { in east, south and west orientation at Nis, } \\
\text { Serbia. }\end{array}$ \\
\hline
\end{tabular}

\section{Methodology}

The installation of solar panels with the ideal orientation and optimum tilt angle for a region enables a higher amount of solar energy to be generated which will benefit the user. This study is designed to determine the best tilt angle and orientation of PV panels for the research location. The PV panels are set up with three different orientations and eleven types of tilt angles for each solar panel. In order to increase the accuracy of the data obtained, field testing was conducted where six solar panels were located at Padang Besar with the study duration of ten selected days within July 2017.

\subsection{Description of research location}

The study location is at Padang Besar which lies within the latitude $6^{\circ} 38^{\prime} 58^{\prime \prime} \mathrm{N}$ and longitude $100^{\circ} 15^{\prime} 23^{\prime}$ ' E. The building studied is a 3-storey commercial building at UniCITI 
ALAM, Padang Besar, Perlis. The roof design of this building consists of two orientations of roof types with roof type A (facing North $70^{\circ}$ East) for positive tilt angle and roof type B (facing South $20^{\circ}$ East) for positive tilt angle. Where the tilt angle of the PV panel is the angle between the solar panel and the horizontal plane.
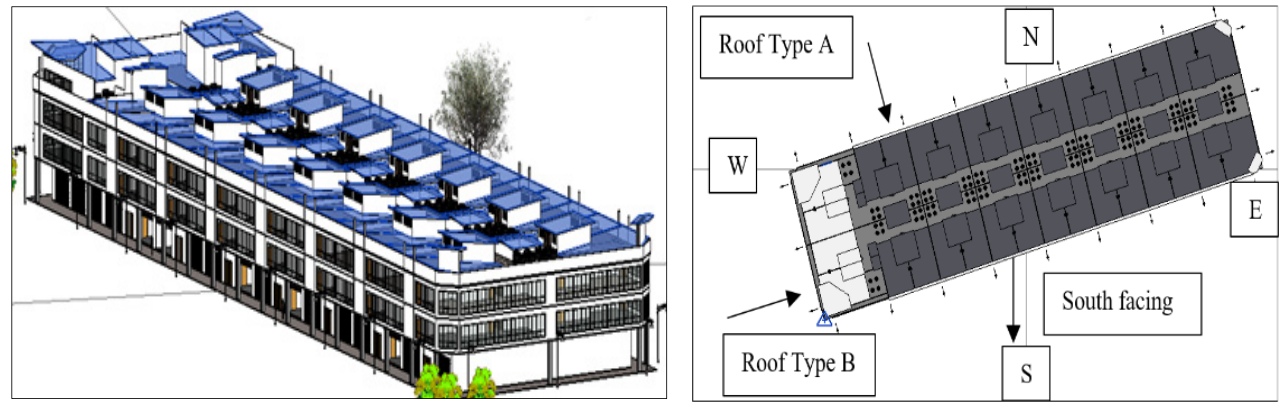

Fig. 1. The illustration of the roof design of the research building with $3 \mathrm{D}$ and $2 \mathrm{D}$ plan view.

\subsection{Installation of solar PV panels}

Six solar panels are placed on the roof area of UniCITI ALAM Block S3. Each solar panel is adjusted with eleven tilt angles from $-25^{\circ}$ to $+25^{\circ}$ with an interval of $5^{\circ}$ to observe the changes of solar irradiance received by each tilt angle. Two solar panels are set for each roof orientation. There are three different directions which cover roof type A (facing North $70^{\circ}$ East for positive tilt angle), roof type B (facing South $20^{\circ}$ East for positive tilt angle) and facing directly towards the south (facing $180^{\circ}$ for positive tilt angle).

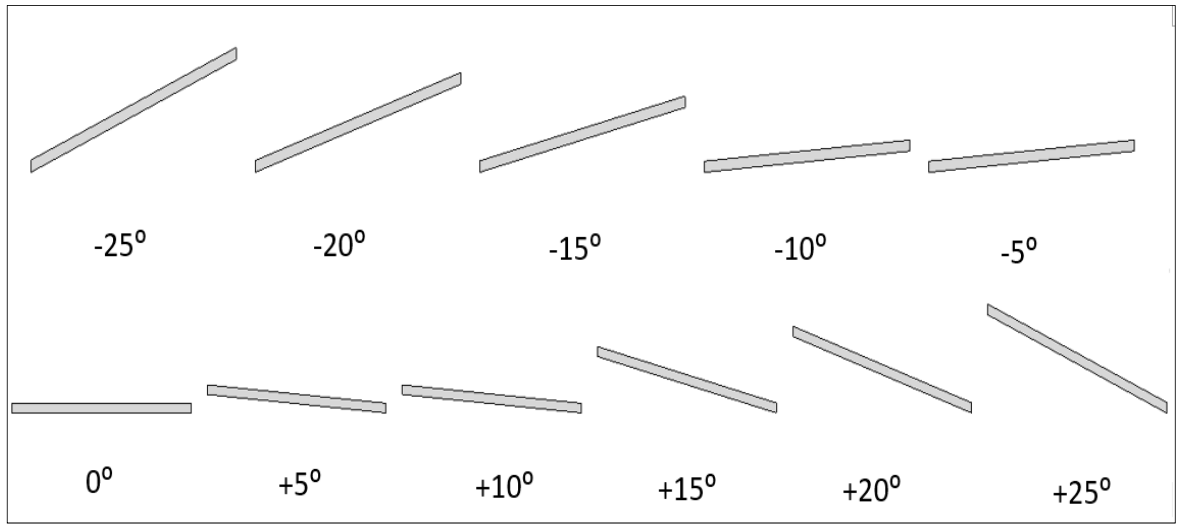

Fig. 2. Illustration of the tilt angle for the PV panels.

\subsection{Data collection and monitoring process}

Data collection of this research covers a number of observations and considerations of the parameters. First, the amount of solar irradiance received for each tilt angle and orientation, is measured using the solar irradiance meter in order to observe the changes of solar irradiance received due to the changes of tilt angle for each orientation. Besides, power generated by solar panels are also recorded with the aid of a solar power generation kit to obtain the readings of current and voltage for each tilt angle and orientation to observe the association between power generated by the PV panel. The research was carried out on the 
$3^{\text {rd }}, 5^{\text {th }}, 7^{\text {th }}, 10^{\text {th }}, 12^{\text {th }}, 14^{\text {th }}, 17^{\text {th }}, 19^{\text {th }}, 21^{\text {st }}$ and $24^{\text {th }}$ of July 2017 with 8 hours per day $(9$ a.m. to 5 p.m.). The data for each parameter were recorded at one-hour intervals.

\subsubsection{Site measurement (solar irradiance)}

The equipment used for solar irradiance data collection on the site is SEAWARD irradiance meter which covers the solar irradiance readings and tilt angle for the set-up of PV panels. Data of solar irradiance is recorded for the three orientations with eleven tilt angles as the PV panel set up. The data obtained is then tabulated to observe the changes for each hour and averaged for the comparison between the three orientations to determine the best tilt angle for the testing duration.

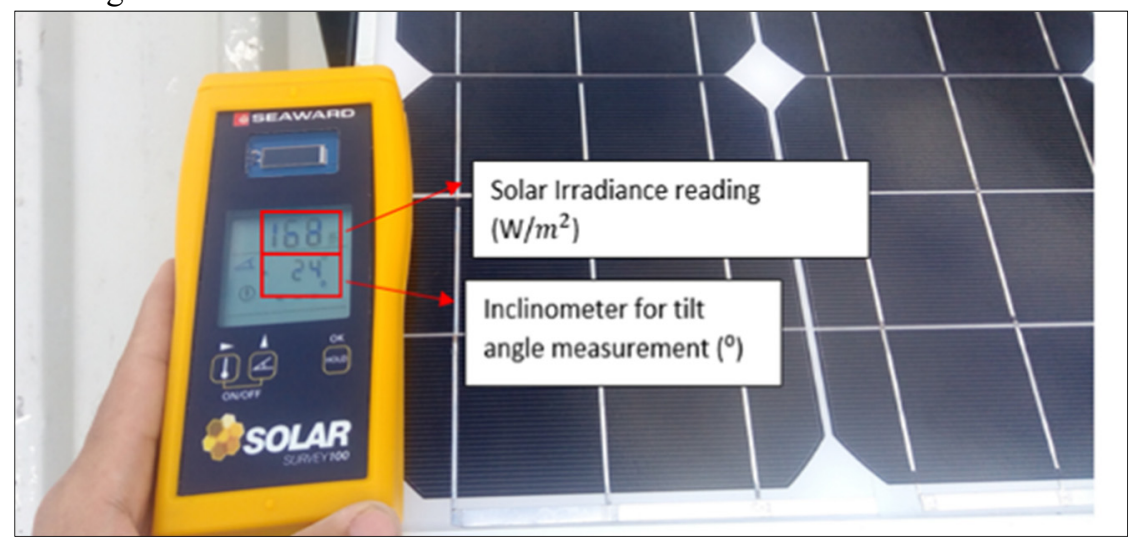

Fig. 3. Placement of solar irradiance meter for tilt angle measurement and irradiance data collection.

\subsubsection{Site measurement (power generated by solar PV)}

A solar power generator training kit was used to collect the data of the power generated by the PV panels to observe the changes of its values for the eleven tilt angles from the three orientations. Data for power generated is averaged from two PV panels for each orientation and tilt angle to reduce error and tabulated in excel for further analysis. 

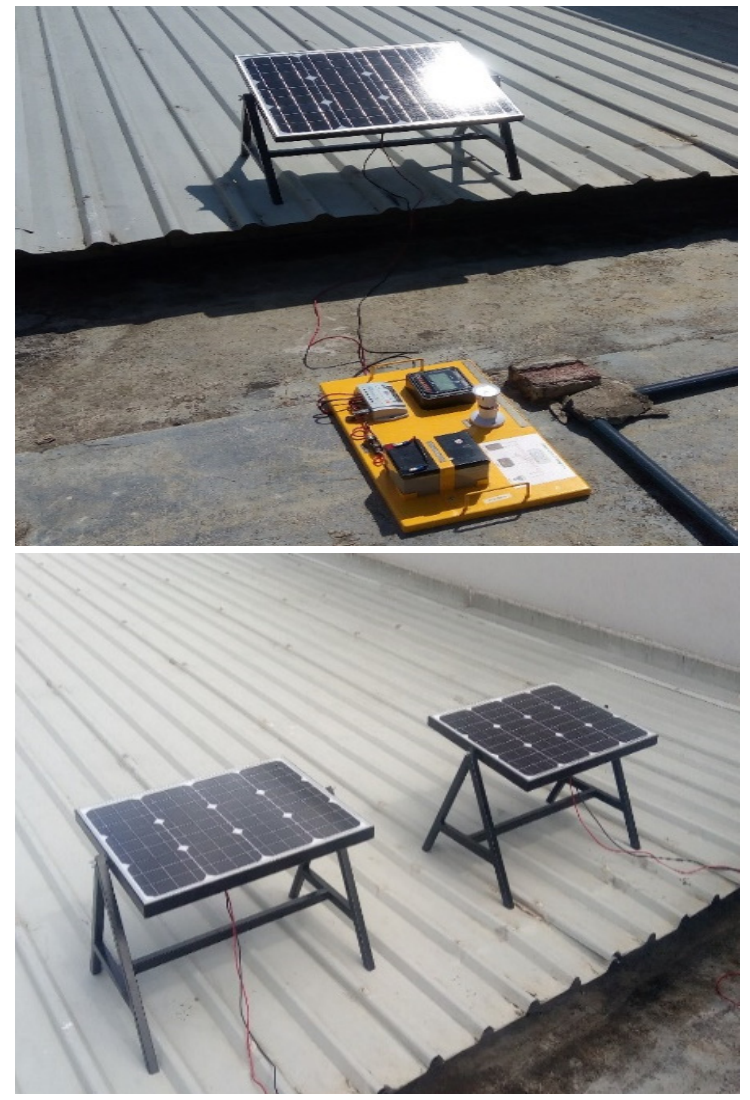

Fig. 4. Setting up of solar PV module for field testing for Roof A orientation.

\subsubsection{Specification of measuring equipment}

Table 2 shows the technical specification of the irradiance meter used in the data collection. Electrical characteristics of the PV panel used in this study is also shown in Table 3. These are important in explaining the limitation of the data collector and the efficiency level of the PV panel for this study.

Table 2. SEAWARD irradiance meter technical specification (source: Solar Power Mart)

\begin{tabular}{|c|c|}
\hline \multicolumn{2}{|c|}{ Irradiance meter } \\
\hline Display Range & $0-1500 \mathrm{~W} / \mathrm{m}-2$ or $30-500 \mathrm{BTU} / \mathrm{hr}-\mathrm{ft} 2$ \\
\hline Measurement Range & $100-1250 \mathrm{~W} / \mathrm{m}-2$ or $30-400 \mathrm{BTU} / \mathrm{hr}-\mathrm{ft} 2$ \\
\hline Resolution & $1 \mathrm{~W} / \mathrm{m} 2 / 1 \mathrm{BTU} / \mathrm{hr}-\mathrm{ft} 22$ \\
\hline \multicolumn{2}{|c|}{$1 \mathrm{~W} / \mathrm{m} 2 / 1 \mathrm{BTU} / \mathrm{hr}-\mathrm{ft} 22$} \\
\hline Display Range & $0^{\circ}$ to $360^{\circ}$ \\
\hline Measurement Ranges & $0^{\circ}$ to $360^{\circ}$ \\
\hline Resolution & $1^{\circ}$ \\
\hline Display Range & $0^{\circ}$ to $90^{\circ}$ \\
\hline Measurement Ranges & $0^{\circ}$ to $90^{\circ}$ \\
\hline Resolution & $1^{\circ}$ \\
\hline
\end{tabular}


Table 3. Electric Characteristics of PV panel (source: Solar Power Mart)

\begin{tabular}{|c|c|}
\hline \multicolumn{2}{|c|}{ ELECTRICAL CHARACTERISTICS } \\
\hline \multicolumn{2}{|c|}{ Values at Standard Test Conditions STC $\left(\right.$ AM $\left.1.5,1,000 \mathrm{~W} / \mathrm{M}^{2}, 25^{\circ} \mathrm{C}\right)$} \\
\hline Max Power, Pmax & $20 \mathrm{Wp}$ \\
\hline Max Power Voltage, Vmp & $17.6 \mathrm{~V}$ \\
\hline Max Power Current, Im & $1.14 \mathrm{~A}$ \\
\hline Open-Circuit Voltage, Vo & $21.3 \mathrm{~V}$ \\
\hline Short-Circuit Current, ISC & $1.22 \mathrm{~A}$ \\
\hline Cell Efficiency & $15.1 \%$ \\
\hline Module Efficiency & $10.2 \%$ \\
\hline Maximum System Voltage & $3 \%$ \\
\hline Power Tolerance & $10 \mathrm{~A}$ \\
\hline Series Fuse Rating & $-0.45 \% /{ }^{\circ} \mathrm{C}$ \\
\hline Temperature Coefficients of, Pmax & $-0.35 \% /{ }^{\circ} \mathrm{C}$ \\
\hline Temperature Coefficients of, Voc & $0.05 \% /{ }^{\circ} \mathrm{C}$ \\
\hline Temperature Coefficients of, ISC & $47{ }^{\circ} \mathrm{C}$ \\
\hline NOTC & \\
\hline
\end{tabular}

\subsubsection{Solar insolation analysis by using BIM 3D modelling software}

For the solar analysis, there are two 3D models constructed to compare the difference in terms of the solar insolation exposure level on the roof surface of the building. The first model is built based on the original roof design while the second model is built with the proposed roof design where the roof is tilted based on the best tilt angle and orientation of PV panels obtained from the field testing. In order to simulate the solar exposure value of the roof surface of each roof surface at research location, the Insight 360 solar analysis plug-in is used in the BIM software (Revit) to perform the solar analysis on model surface exposure to solar insolation due to seasonal variation and tilt angle. The input, such as true north of the building model and research location, is inserted. The true north setting is adjusted based on the project's reference point while the location is set with the aid of an internet mapping service. The duration of study and observation duration for each day are also set in the plugin before proceeding with the selection of model surface for solar insolation analysis. The model constructed as shown in figure 5 is the original roof design for the building studied and the surface for the solar insolation analysis is divided into 72 surfaces.

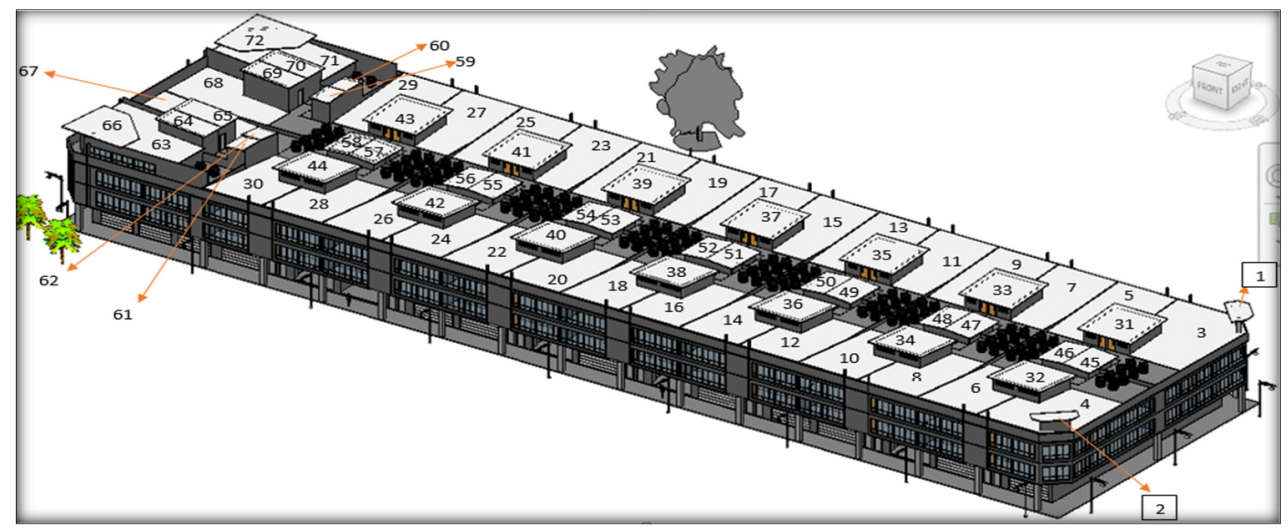

Fig. 5. Layout of the roof label for the roof on the Block S3 building at the research location for the solar insolation analysis of the BIM software. 
Next, a solar insolation analysis is then performed and the data are generated in the form of Comma separated value text files (.CSV file) which will be viewable in Excel Spreadsheet. The data produced by the plug-in analysis includes the analytical surface, average surface insolation value, surface area and total surface insolation value. Further analysis of these data is performed with the data tabulation and a comparison is then made between the two model roofs in terms of solar insolation exposure with the aid of figure technique.

\section{Results and discussions}

The changes of the average solar irradiance received for each hour throughout the ten days of data collection for each of the eleven tilt angles and three orientations are as shown in figure 6,7 and 8 .

\subsection{Effect of orientation and tilt angle on the amount of solar irradiance received}

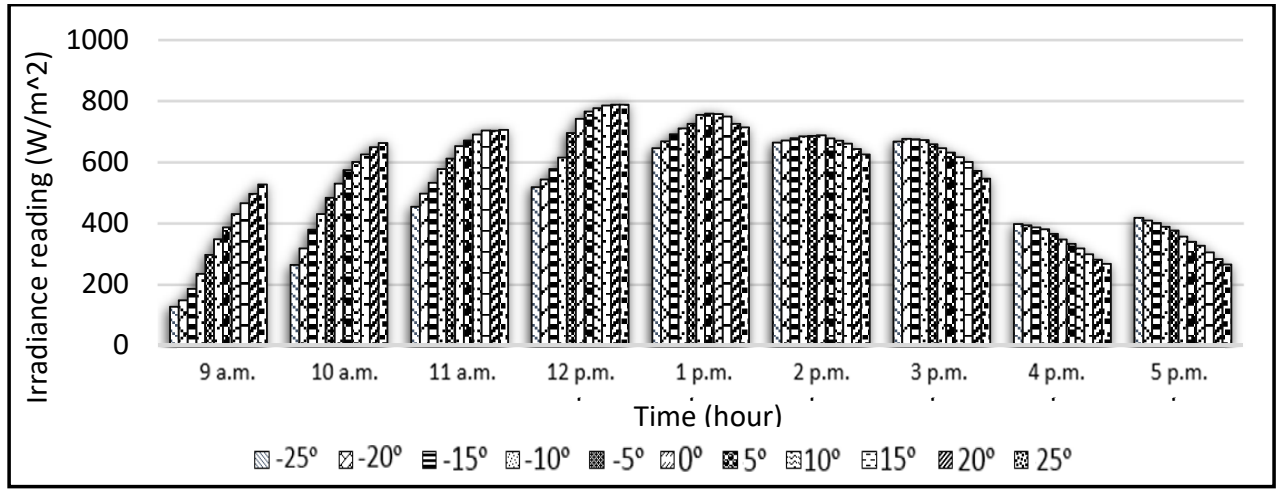

Fig. 6. The average readings of solar irradiance $\left(\mathrm{W} / \mathrm{m}^{2}\right)$ with different tilt angle, over the field-testing period with the orientation of North $70^{\circ}$ East for positive tilt angle.

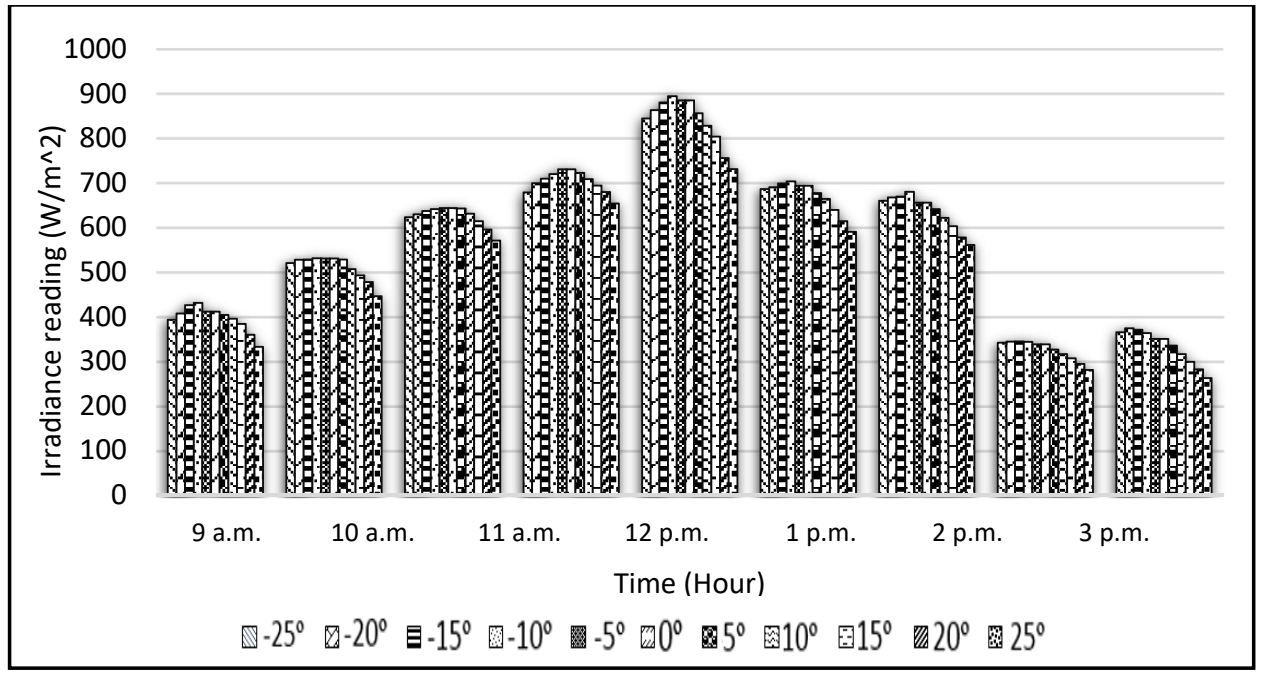

Fig. 7. The average readings of solar irradiance $\left(\mathrm{W} / \mathrm{m}^{2}\right)$ with different tilt angle, over the field-testing period with the orientation of South $20^{\circ}$ East for positive tilt angle. 


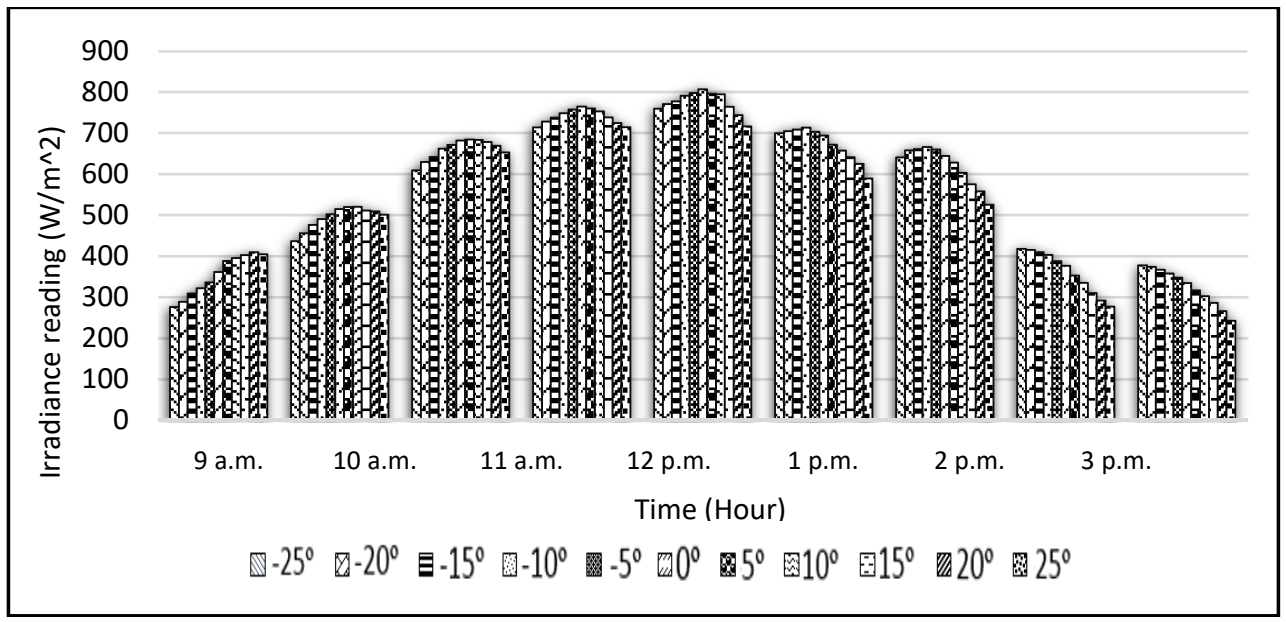

Fig. 8. The average readings of solar irradiance $\left(W / \mathrm{m}^{2}\right)$ with different tilt angle, over the field-testing period with the orientation of South.

Based on figure 6,7 and 8, changes of solar irradiance values obtained displayed that the maximum amount of solar irradiance reaches the research location at $1 \mathrm{p} . \mathrm{m}$. with the highest average reading of $718.21 \mathrm{~W} / \mathrm{m}^{2}, 840.4 \mathrm{~W} / \mathrm{m}^{2}$ and $774.98 \mathrm{~W} / \mathrm{m}^{2}$ respectively for each orientation. The variance of solar irradiance range from $35.3 \mathrm{~W} / \mathrm{m}^{2}$ to $400.7 \mathrm{~W} / \mathrm{m}^{2}$ within an hour among the eleven tilt angles. It is observed that the solar panels with the orientation of the South $20^{\circ}$ East received the highest average amount of solar irradiance throughout the test duration.

\subsection{Comparison between the average irradiance reading and power generated for the different tilt angel and orientation of PV panels.}

Figure 9 shows the comparison of average solar irradiance obtained for each tilt angle and orientation by using irradiance meter. On the other hand, figure 10 shows the comparison of the average output power generated by PV panels for each tilt angle and orientation. 


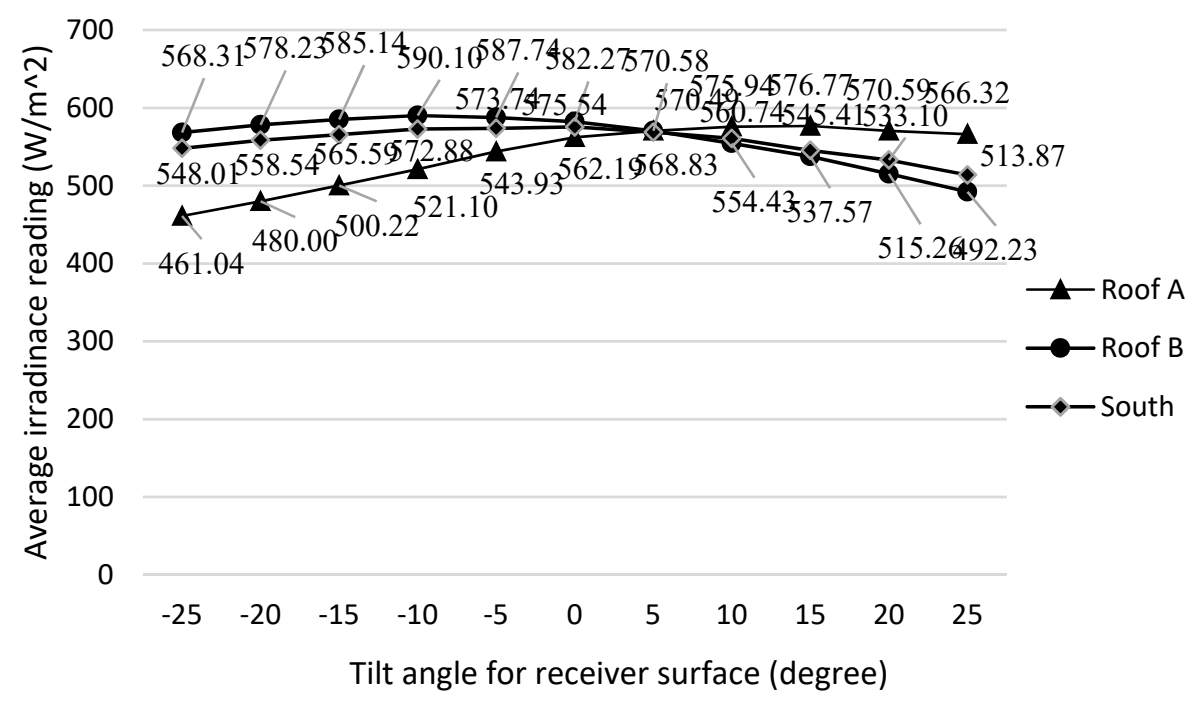

Fig. 9. Comparison of average solar irradiance for each tilt angle and orientation.

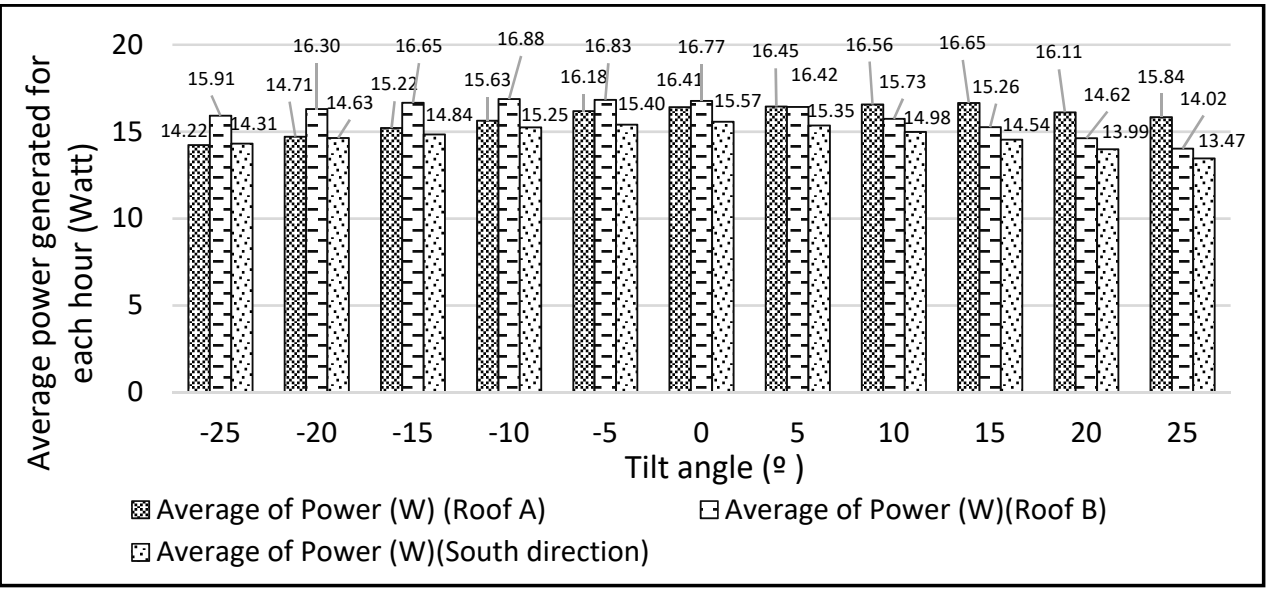

Fig. 10. Comparison of average output power for each tilt angle and orientation.

Based on figure 9 and figure 10, the average solar irradiance received from North $70^{\circ}$ East (Roof A) as positive tilt angle and vice versa, lies between the range of $461.04 \mathrm{~W} / \mathrm{m}^{2}$ to $566.32 \mathrm{~W} / \mathrm{m}^{2}$. On the other hand, the solar panels facing South $20^{\circ}$ East (Roof B) harvested the solar irradiance ranging from $492.23 \mathrm{~W} / \mathrm{m}^{2}$ to $590.1 \mathrm{~W} / \mathrm{m}^{2}$. In the case where the solar panels are facing South as positive tilt angle, the exposure level of solar irradiance indicates a difference of $61.68 \mathrm{~W} / \mathrm{m}^{2}$ between the highest value obtained $\left(575.54 \mathrm{~W} / \mathrm{m}^{2}\right)$ and lowest irradiance value obtained $\left(513.87 \mathrm{~W} / \mathrm{m}^{2}\right)$ with a difference of $25^{\circ}$ of tilt angle. This indicates that the tilt angle of PV panel is important in manipulating the exposure level to solar insolation.

For the part of average power generated by PV panels, the tilt angle of $-10^{\circ}$ facing South $20^{\circ}$ East for positive tilt angle gives the highest energy production with 16.88 Watt, which is the highest among the three orientations followed by 16.65 Watt for the panel facing South 
$20^{\circ}$ East for positive tilt angle and 15.57 Watt for panel facing South. The same trend of data showed that the orientation of roof $\mathrm{B}$ with $-10^{\circ}$ tilt angle is the best tilt angle in the study.

\subsection{Comparison of total surface insolation amount among original model with proposed roof model.}

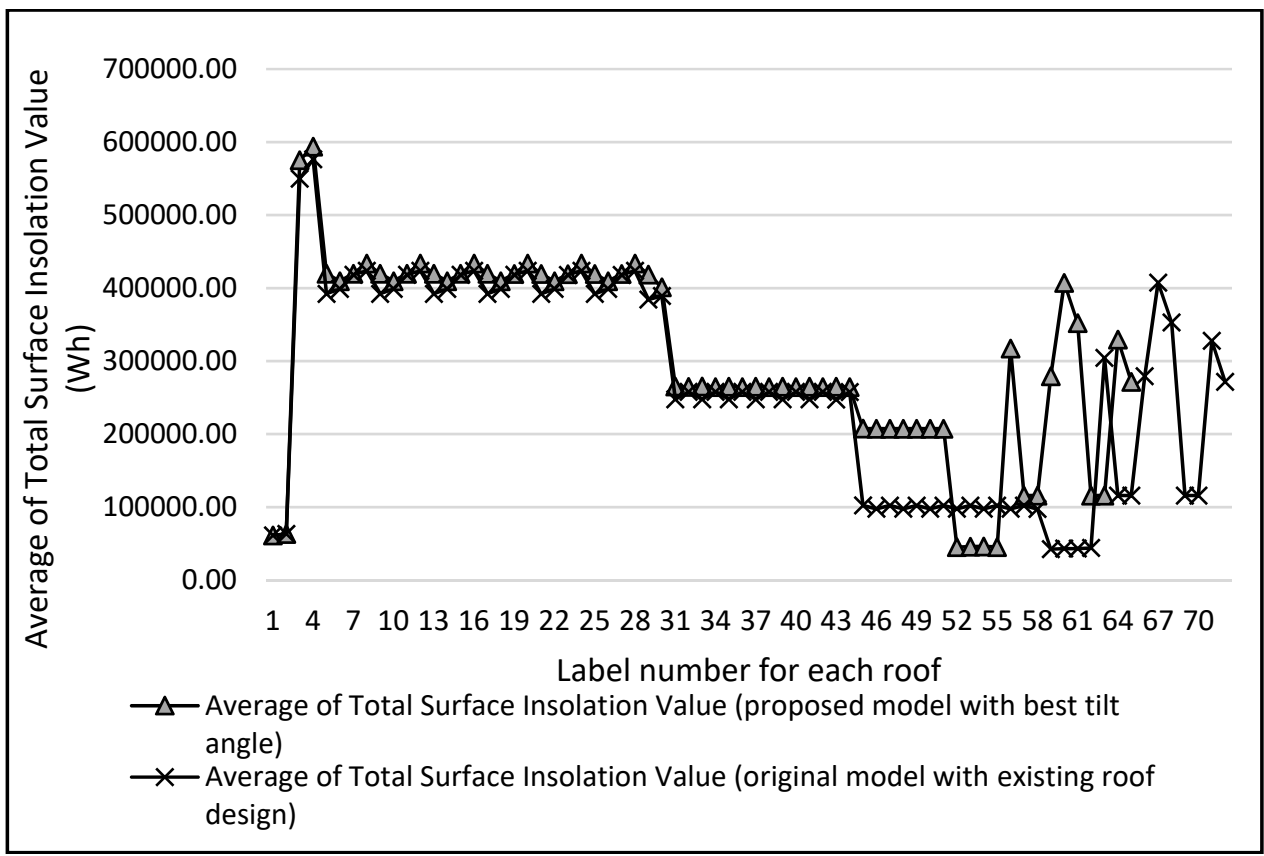

Fig. 11. Comparison of average of total surface insolation value at each roof between original model and proposed model.

The solar insolation analysis is then carried out for the proposed model. From the data, $86.07 \%$ out of the original roof was covered with the best tilt angle and orientation of the surface which was planned to be attached with PV panel. Figure 11 displays the trend of the average surface insolation value and the total surface insolation value. The highest amount of total solar insolation received for the existing roof design is $576559.22 \mathrm{Wh}$ while the proposed roof design is 593914.29 Wh. This indicates that the proposed roof design has a higher exposure level towards the solar insolation .

On the other hand, the overall average total solar insolation data obtained using the solar insolation analysis with the consideration of surface area (per square metre) shows that the proposed model received $43922.83 \mathrm{Wh} / \mathrm{m}^{2}$, which enables an increase of $1.45 \%$ compared to the original model which is just $43295.46 \mathrm{Wh} / \mathrm{m}^{2}$ model that applies the best tilt angle and orientation for July 2017 which was obtained from the field measurement.

\section{Conclusion}

The aim of this study is to investigate the best tilt angle and orientation of PV panel in Padang Besar, Perlis for July 2017 using solar irradiance data and power generated by PV panels. As shown in this paper, the tilt angle and orientation of solar panels plays an important role in contributing to the variation in terms of solar irradiance exposure and followed by the power generated by a PV panel. 
These methods produced a similar output where the best tilt angle and ideal orientation for PV panels is $-10^{\circ}$ with orientation: facing South $20^{\circ}$ East for positive tilt angle on July 2017. In addition, the maximum amount of solar irradiance is attained at 1 p.m. at the research location and reduction of solar irradiance received increased as the differences between tilt angle and best tilt angle is increased. This directly lowered the output power generated by the solar panel. The orientation of the solar panels results in variations in the power generated ranging from 0.09 Watt to 2.37 Watt. The finding from solar analysis of the proposed model indicates that solar insolation exposure on the roof per square metre increased by $1.45 \%$ compared to the existing roof design. Therefore, this can increase the renewable energy potential in an effective way.

This author acknowledges the Faculty of Engineering Technology, University Malaysia Perlis (UniMAP) for the contribution in term of lab facilities and the financial support received under the Fundamental Research Grant Scheme (FRGS: Grant No. 900300105) provided by the Ministry of Higher Education of Malaysia (MOHE). The author is also grateful to the Department of Electrical Engineering Technology, Universiti Malaysia Perlis (UniMAP) and Proven Properties (M) Sdn. Bhd. in providing equipment and site in this project.

\section{References}

1. Syed Shah Alam, Nor Aisah Omar, Mhd. Shuhaimi Bin Ahmad, H.R. Siddiquei, \&Sallehuddin Mohd. Nor, Renewable Energy in Malaysia: Strategies and Development. Environmental Management and Sustainable Development, 2013, 2, No. 1 (2013)

2. Laith Sa'd Basha, (2012). Analysis and Evaluation Tools Development Of Photovoltaic Modules And System Performance Under Jordanian And German Climatic Conditions, 8-13 (2012)

3. Azman, M., Brief Outlook on Malaysia Electric Supply Industry, TNB \& Malaysia National Outlook of CIGRE (MNC-CIGRE). Plenary Session for Power Industry, (p. 22). Guangzhou, China: Tenaga Nasional Berhad (2013)

4. Klaus, J., Olindo, I., Arno H.M., S., René A.C.M.M., v., \& Miro, Z., Solar Energy. Delft, the Netherlands: Delft University of Technology, 50-57 (2014)

5. Fillppo, G, Sun position and PV panels: a model to determine the best orientation. Student thesis series INES nr 360, 7-16 (2015)

6. I. Daut, Y.M. Irwan, I. Safwati, M. Irwanto, N. Gomesh, \& M. Fitra, Finding the Outliers on Solar Radiation in Northern Malaysia, Perlis. Asian Transactions on Engineering (ATE ISSN: 2221-4267), 2 Issue 03, 35-40 (2012)

7. I. Daut, Farhana Zainuddin, Y.M. Irwan, \& A.R.N. Razliana, Analysis of Solar Irradiance and Solar Energy in Perlis, Northern of Peninsular Malaysia. Energy Procedia 18, 1421-1427 (2012)

8. Rob Garner, \& Brian Dunbar, Solar Irradiance. Retrieved from NASA TV: https://Www.nasa.gov/mission_pages/sdo/science/solar-irradiance.htm/ (2008, January 2)

9. Ionel L. Alboteanu, Cornelia A. Bulucea, \& Sonia Degeratu, Estimating Solar Irradiation Absorbed by Photovoltaic Panels with Low Concentration Located in Craiova, Romania. Sustainability 2015, 7, 2644-2661 (2015) 
10. Suresh N, Jayaprakash R, \& Dhanabagyam S, Solar Radiation Measurments, Angle of Inclination, Solar Irradiance for Solar Water Purification System. International Journal of Current Multidisciplinary Studies, 98-100 (2015)

11. Rupesh Patel, Design and Implementation of an Isolated Solar Photovoltaic Power Generation System. 7-20 (2014)

12. Mohanty, P., Muneer, T., Gago, E. J., \& Kotak, Y, Solar Radiation Fundamentals and PV System Components. Solar Photovoltaic System Applications, Green Energy and Technology, 7-14 (2016)

13. Swami, R, Solar Cell. International J. of Sci. and Research Publications, 2, Issue 7, 2-3 (2012)

14. Zeinab Abdallah M. Elhassan, Mohammad Fauzi Moh. Zain, Kamaruzzaman Sopian, \& Arafa Awadalla, Output Eneryg of Photovoltaic Module Directed at Optimum Slope Angle in Kuala Lumpur, Malaysia. Research J. of Appl. Sci. 2, 104-109 (2011)

15. B. Kamanga, J. S. P. Mlatho, C. Mikeka, \& C. Kamunda, Optimum Tilt Angle for Photovoltaic Solar Panels in Zomba District, Malawi. J. of Solar Energy Volume 2014, 1-9 (2014)

16. K.R. Ajao, R.M. Ambali, \& M.O. Mahmoud, Determination of the Optimal Tilt Angle for Solar Photovoltaic Panel in Ilorin, Nigeria. J. of Eng. Sci. and Tech. Review 6 (1), 87-90 (2013)

17. T. Pavlović, Z. Pavlović, L. Pantić, \& Lj. Kostić, Determining Optimum Tilt Angles And Orientations Of Photovoltaic Panels In Nišs, Serbia. Contemporary Materials I-2, 151-156 (2012) 